\title{
JÁNOS KORNAI AS POLITICAL ECONOMIST
}

\author{
Stephan HAGGARD
}

\begin{abstract}
Although writing as an economist, János Kornai addressed fundamental questions of political economy throughout his career. These considerations began with his model of state socialist economies, but were explicit in his work on transitions and the political economy of reform as well. This paper provides an overview of those contributions, with a particular attention to the relationship between regime type - democracy and authoritarian rule - and economic structures, processes, and outcomes.
\end{abstract}

Keywords: socialism, communism, democracy, transitions, economic reform

JEL classification indices: B2, B5, P2, P3, P5

Stephan Haggard, Krause Distinguished Professor at the School of Global Policy and Strategy, University of California, San Diego. E-mail: shaggard@ucsd.edu 
"The key to understanding of the socialist system is to examine the structure of power, which receives little or no attention in many comparative studies of economic systems."

János Kornai, The Socialist System (1992, p. 33).

János Kornai was, of course, trained and wrote as an economist. But throughout his career, he chafed against orthodoxy and in part because of its inattention to institutional and political factors. Sometimes, this focus was more implicit, as in Anti-Equilibrium, in which he took on the just-so world of general equilibrium theory. At other times, it was more explicit, as the epigraph above attests. The subtitle of The Socialist System was The Political Economy of Socialism. That book - still the most comprehensive comparative analysis of state socialist systems - was not called The Socialist Economic System for a reason.

First, and at the deepest level, Kornai consistently argued that the socialist economic system was a direct outgrowth of its political structure rather than the other way around. This idea had a longer pedigree in critics such as Hayek, whose Road to Serfdom was among the first to make the point. But Kornai had a particularly nuanced conception of how this elective affinity worked. Conversely, his work on transitions saw that process as fundamentally political as well, with the shift from socialism to the market operating hand-in-glove with the emergence of democracy and the protection of political, civil, and property rights. This debate - essentially on the relationship between democracy and the market - remains a central one in both positive and normative political science and his contributions to it, particularly in The Road to a Free Economy, bear careful reading.

Second, a political economy is necessary at a more disaggregated level because characteristic features of both communist and capitalist economic systems are embedded in incentives related to their political, institutional, and organizational structure. The concept of the soft budget constraint is no doubt Kornai's most visible contribution in this regard. But as I will also show, the point was a more general one: that beneath the surface façade of hierarchy, socialist systems were riven with internal politics between the different levels of party and government, and even between the government and citizens.

Kornai's interest in things political persisted in his later explorations of the transition process, both in Hungary and in the former socialist countries more generally. These highly dynamic shifts in institutions were a world away from the general equilibrium models that Kornai criticized in Anti-Equilibrium. They were also politically charged and could only be understood in terms of what political scientists called the "dual transition” (Przeworski 1991): both from socialism as an economic system and from authoritarian rule to democracy. Some of the 
findings are counterintuitive. For example, Kornai links political and economic freedom, making both positive and normative arguments for liberalization. But he also notes that democratic governments need to act swiftly and decisively with respect to economic reforms and exercise ongoing discipline with respect to public finances. This decisiveness and discipline must ultimately emanate from political authority vested in parliaments reflecting the public interest, even where there are short-term costs to portions of the electorate.

In this paper, I offer a critical appreciation of Kornai's political economy, both highlighting significant contributions and showing how his work connected with parallel developments in political science. These developments included both research on socialist systems, which remains very much alive because of the persistence of Communist rule in China, Vietnam, North Korea, and Cuba, and an even larger literature on the political economy of economic reform, social policy, and democracy itself.

\section{ANTI-EQUILIBRIUM}

Political scientists have poached extensively on economics, and at important margins the fields are probably closer to one another now than they have been for some time. This is true with respect to the use of formal theory, common econometric techniques, and in the substantive area of political economy in particular. Nonetheless, political scientists were never seized of the line of general equilibrium theory (GET) that grew out of Arrow - Debreu (1954) to anywhere near the extent that economists were. Not coincidentally, probably the only other general theory of this sort in all of political science was also authored by Arrow in his Social Choice and Individual Values (1951). ${ }^{1}$

There are many reasons for this inattention. They start with the historical fact that the field of political economy was only to develop and converge with economics in subsequent decades. But it also rests on the fact that political scientists have a particular interest in the way that politics introduces distortions into the general equilibrium world; we are interested less in this fundamentally normative baseline than in the political forces that are likely to upset it in various ways.

Let me start with some observations on theory and method. Read from the early $21^{\text {st }}$ century, one aspect of Kornai's critique of GET is surprisingly fresh, although it was sharply criticized at the time (for example, Hahn 1973). In drawing

One might be viewed as a "possibility theorem" - that there is a market-clearing equilibrium that is Pareto efficient - the other an "impossibility theorem" of turning ranked preferences into a coherent social choice in the absence of a dictator. 
his distinction, posed in contentious language, between "logical-mathematical" sciences and "real sciences" he pinpointed a fundamental epistemological problem that is unsolved to this day. How exactly do we move from deductive models, whether choice or game-theoretic, to empirical work?

At one point, logical positivists believed that this circle could easily be squared by constructing a unified, logico-deductive underpinning to all science. But those days were waning by the time Arrow - Debreu (1954) appeared even in the philosophy of the natural sciences. There was even less consensus that the social sciences could - or should - try to emulate such a model. Kornai is insistent in Anti-Equilibrium that decision theory and what he calls "intellectual experiments" are not a substitute for empirical analysis. First, there is the problem of whether the particular assumptions required to attain closure of a formal model are adequate to the empirical task at hand; Kornai was clearly critical of the assumptions undergirding the Arrow-Debreu model and whether they were plausible. But second, even if this problem of realism were to be solved, there is no easy mapping from the variables in a formal model to empirical specification. In the end, I have come to pragmatist conclusions on these questions that I think broadly mirror Kornai's. Is the model useful or not? But to this day, the question of whether models such as Arrow and Debreu's are fundamentally normative and whether they are subject to empirical test at all remains open.

The core feature of Kornai's critique in Anti-Equilibrium proceeded along another track however: to remind the reader of the long and restrictive list of assumptions that must pertain for the general equilibrium result to hold. Many of these assumptions such as those on uncertainty, search, and information costs were fruitfully relaxed to push towards new insights. But one consistent subtheme of Kornai's critique (and of criticisms of Arrow's impossibility theorem as well) centers on the role of institutions. At the very start of his effort to reconstruct an alternative paradigm, Kornai leads with a definition of "the economic system". He starts with its core component parts: "the institutions, the organizations within the individual institutions, and the units within the individual organizations" (p. 37, emphasis in original). He subsequently goes on to talk about the "real" and "control" spheres. The latter is clearly intended to include actors exercising control not only with respect to individual units (the producers and consumers in the Arrow-Debreu framework) but with respect to the political economy as a whole.

Politics also enters in his assertion - fundamental to virtually all political thought - that the underlying preferences of actors are not necessarily aligned, as they might be in a purely economic exchange. As a result, conflicts of interest have to be reconciled in some way (pp. 92-97). These observations imply, 
although they are not spelled out in Anti-Equilibrium, the significance of higherorder institutions such as property rights and dispute resolution mechanisms.

With respect to the role of government, Kornai's explicit treatment in AntiEquilibrium is fairly abbreviated (pp. 151-153). He makes two main claims. The first is somewhat confusing: governments do not make decisions based on a fixed preference ordering. I think Kornai is making a temporal point: that governments change and, as a result, governments' preference orderings also shift in ways which might not be true of firms or households. This is hardly controversial to a political scientist; one important strand of political economy research looks at partisan business cycles and the importance of shifting government preferences. The second observation Kornai offers on government is that some of the most significant decisions regarding the economic system bear little resemblance to the many production and consumption decisions that drive markets. Rather, they are rare events that have wide parametric effects. This too is not particularly controversial, but does raise the question of how such decisions are to be modeled and studied. I do not see Anti-Equilibrium attempting an answer to that question, even in schematic form, but it is in some sense the motivating question of The Socialist System and his subsequent work on transitions.

Kornai did not explicitly state that his objective in Anti-Equilibrium was to produce a contrasting political economy to GET, so the following question might be unfair. Was Anti-Equilibrium successful in outlining such a broader political economy? My answer, frankly, is mixed. On the one hand, Kornai succeeds in reminding readers of the restrictive conditions that have to hold for GET to work, although most of those central challenges pertain to economic features of the Arrow-Debreu model (see particularly Kornai 1971: 18-31). He also does a compelling job in reminding the reader of the institutional and organizational complexity of any given economy and thus introduces realism; indeed, this is arguably the book's central purpose. And in a section which extends beyond my interest here, he provides an example that purports to follow from the theory when he draws an ideal-typical distinction between economies characterized by "pressure" and "suction", a prelude to his subsequent analysis of the shortage economy.

Yet in the end, I am not sure that Anti-Equilibrium succeeds in constructing an alternative disequilibrium political economy. Much of the book is taken up with descriptive and categorical work: introducing entities and relationships that are to be modeled through a complex combination of decision processes, response functions, and cybernetic feedback loops. In later works, most notably in The Economics of Shortage (1980) and The Socialist System (1992), I believe he moves to a framework rooted in principal-agent models that were subsequently 
embraced by most political scientists (for example, Moe 1984). As a result, he derives sharper "if-then" propositions about how socialist economies work at both the macroeconomic and microeconomic level. Kornai may see this as a loss of the generality to which he aspired in Anti-Equilibrium, but I am not convinced this intellectual move was a bad thing.

\section{THE ANALYSIS OF SOCIALIST SYSTEMS}

\section{The classical system}

From the start of his career, Kornai was always interested in practical problems, and as a Hungarian that naturally meant understanding socialist systems. This work is done throughout his career, with Overcentralization (1959/1994), The Economics of Shortage (1980), and The Socialist System (1992) constituting important landmarks. The latter must certainly be counted among the great works of comparative economics and political economy. It paints both an ideal-typical theoretical model of such systems and provides rich empirical detail from the analysis of the more significant cases. Fortunately or unfortunately for its reception, the book almost perfectly reflects the Hegelian dictum that "the owl of Minerva spreads its wings only with the falling of the dusk"; it was published just as the Soviet Union collapsed. Although a number of themes of The Socialist System are introduced in earlier work, I will use it as an organizing device for understanding his approach to the political economy of communism.

Toward the outset of The Socialist System, Kornai lists the general factors he deems significant in this regard, and they are perennial: the effects of political institutions on the economy; how social factors influence decision-makers; and how principal-agent relationships influence decisions and economic performance (Kornai 1992: 12). Before turning to his model of the socialist system, however, Kornai provides a short introduction to the transition to the "classical" socialist system that contains fundamental insights into the nature of these economies (Kornai 1992: 26-30).

In particular, he makes an important claim "that no socialist system has ever been installed in power by internal forces in any developed capitalist economy." Missing from that sentence, but strongly implicit in it, is the word "democratic": that socialism of the sort that Kornai describes has never been the resultant of democratic political processes. Rather, socialism arises not simply in revolutionary settings - a self-congratulatory and self-justificatory trope of the militant left - but ones in which war plays a central role (see, for example, Skocpol 1979). To use a socialist expression, war heightens the contradictions in backward societies, 
exacerbating inequality and social conflict, and simply wreaking destruction from which socialist organizations and ideologies promise reprieve. Most fundamentally, war weakens incumbent regimes and provides an opening for communist challengers. This was true in Russia, in Eastern Europe, ${ }^{2}$ and in China, Vietnam, and North Korea as well. Indeed, only in Cuba does it appear to be the case that a communist revolution succeeds in the absence of wider war.

The reason for this important point in comparative political economy lies in the fact that the first step of the transition to state socialism involves what Kornai calls the "expropriation of the expropriators" (Kornai 1992: 27): the fundamental transformation of private property into nationalized state-controlled entities, and from firms and banks to the agricultural sector and rural landholdings through collectivization. Just as socialism is born of revolutionary authoritarianism, so it is necessarily sustained by the well-known political structures of communist authoritarian rule, a highly distinctive type that stands in contrast both to military authoritarian systems and those where there is a dominant but not completely monopolistic political party (Magaloni - Kricheli 2010).

These features of the communist political structure include the monopoly of political organization by a single party and party control over the state through the creation of parallel structures of control. But they also include the creation of mass organizations that effectively incorporate, monitor, and control all individuals in society, giving these systems there "totalitarian" characteristics. Kornai outlines these features of the system in Chapter three, the first sentence of which is the epigraph above emphasizing the central role of the exercise of political power over society. In Chapter four, Kornai offers an extended discussion of the function of ideology in the system as well, which is not simply to facilitate control, but through exhortation and the use of national and other symbols to align preferences within the state and party and between the party-state and citizens (see, for example, Schurman 1966 on China). Two subsequent chapters detail the nature of property (Chapter five) - dominated but not completely monopolized by state firms - and the general coordination mechanisms that exist in the economy as a whole (Chapter six).

In his summary statement of "classical socialism", however, Kornai is quite explicit that the economic features of the system derive immediately and in the first instance from the system's political structure, which he defines to include both its institutional arrangements and ideology (Kornai 1992: 362-379). Put

2 Kornai does note that multiparty parliamentary democracy operated in a number of the Eastern European countries in the early postwar period, but the war had set the terms of Soviet control and penetration, and the transition paths across Eastern Europe, with the possible exception of Albania and Yugoslavia, look surprisingly constant. 
differently, it is not the dominant position of state- and quasi-state ownership that drives the politics of socialist systems, but rather the other way around. Moreover, Kornai argues that institutions are ultimately paramount to ideology. His reflections on this critical point go not only to core themes in his political economy of socialism, but also to the longstanding debate about the relationship between democracy and the market:

"It is not the property form - state ownership - that erects the political structure of classical socialism over itself. Quite the reverse: the given political structure brings about the property form it deems desirable. Although in this case the ideology plays a marked role in forming society, it is not the sole explanation for the direction of influence. The indivisibility of power and the concomitant totalitarianism are incompatible with the autonomy that private ownership entails. This kind of rule demands heavy curtailment of individual sovereignty. The further elimination of private ownership is taken, the more consistently can full subjugation be imposed" (p. 362).

After setting the broad political and institutional stage, the book's central observations about the operation of the state socialist system emerge in Chapter seven when Kornai turns to what might be called "actually existing planning". This debate has its origins in the so-called socialist calculation controversy, which emerged in the wake of von Mises' critique of socialism and the pitched intellectual battles between the Austrian school and defenders of socialism such as Oskar Lange, Maurice Dobb, and others; early in his career, Kornai wrote on these planning and informational problems in a way that directly echoes those earlier debates (Kornai 1959/1994; Kornai - Liptak 1965). Kornai ultimately came to the view that key features of the socialist economy were rooted in perverse incentives that arise in the planning process and are intrinsic to socialist systems, an integral part of their DNA. These problems are related to imperfect information and bureaucratic slack, exactly the kinds of principal-agent relationships that subsequently came to structure political science thinking about the state itself (again, for example, Moe 1984).

In Section 7.5 (pp. 121-124 and ff.), Kornai introduces these problems of bargaining and what he calls "inner conflict" by outlining a stylized model between a planner, the firm that implements the plan, and what might be called "horizontal" suppliers of needed inputs (which can be extended to purchasers of output as well). This extended game is treated with exquisite attention and helps explain many of the fundamental problems of shortage and other distortions that were presaged in the last substantive section of Anti-Equilibrium and are the meat and potatoes of Economics of Shortage and the economic chapters of The Socialist System. 
The planner is under pressure from political principals - the party apparatus - to produce results; these are "driven" economic systems, committed to rapid industrialization for a complex combination of geostrategic and ideological reasons. The result in the classical system is a focus on investment over consumption, in part responsible for the perennial shortages in consumer goods and services such as housing (Kornai 1992: 160-163). But as I argued with Robert Kaufman in Development, Democracy and Welfare States (2008), state provision of social services in Eastern Europe was not simply a result of ideological commitments, but of the expropriation of private service providers. With de-Stalinization and particularly in what might be called "late socialism" that I take up below, broader political factors also play a role. The socialist social contract takes on a material as well as ideological tones, resting on the promise not only of economic security, but also of increased consumption and leisure (Kornai 1992: 311-332; Dimitrov 2013).

To achieve these investment and consumption objectives, political elites delegate to planners who in turn must elicit effort and output on the part of the state firms. As Kornai notes, and as advocates of scientific planning believed, "under ideal conditions the firms pass accurate information to their superiors, who objectively distribute the tasks so that every firm receives a realistic but mobilizing production assignment and saves materials and labor insofar as possible” (p. 122). But as we know, such monitoring is effectively impossible; there is imperfect information in any organization, and the subordinate has incentives not only to shirk, but to distort and hide information as well. His objective is to maximize inputs while minimizing expectations with respect to output and efficiency. Since the planner is aware of this game, although not necessarily of the precise parameters, there is a counter-effort to "plan in" margins, which in turn meet counterstrategies of passive resistance. As Kornai concludes, "Marx and his followers reckoned that planning would be simple (...) but the practical solution is full of frictions, dysfunctional features, inefficiencies, and internal conflicts” (p. 130).

Perhaps one of the most significant contributions of Kornai's political economy, and one that traveled well beyond socialist systems, was the concept of the "soft budget constraint" (SBC) (Kornai 1979, 1980, 1986; 1992: 140-145; 1997). This concept can be seen as an extension, albeit an important one, of the principal-agent model outlined above. From an economic perspective, Kornai's contribution comes in summarizing the various modalities through which SBC operates (subsidies, soft taxation, and credit, soft administrative prices) and the corresponding economic effects (on firm behavior, on efficiency, on generation of excess demand).

But from a political perspective, the important point to note is how SBC itself is a resultant of bargaining and deeper political processes. In his 1986 summary 
of the concept, he notes that "external assistance is usually not granted automatically, as some effort is needed to obtain it. The firm's managers (and in the case of a private firm, also the owners) must resort to political pressure groups and lobbies, or to personal connections” (Kornai 1986: 7). He explicitly links SBC to Krueger's (1974) concept of rent-seeking. Krueger believed that rent-seeking arose out of political factors on the supply side: in effect, rents created rent-seeking. This is typically the reverse of the way that political scientists think of the issue; rather, it is private actors that seek to extract supernormal returns and control or even capture the state. The interest group, firm, or lobbyist has some leverage over the politician through the mobilization of votes or providing money directly, either legally through campaign contributions or illegally through bribes. The relevance to debates about moral hazard is obvious, for example in the onset of financial crises.

In a later overview, Kornai (1997) sought to differentiate his theory from rentseeking, noting that it is centered on organizational life and death: whether entities can survive a harder budget constraint at all. As a result, it can be extended not simply to firms that are lobbying, but to other organizations as well, such as the relationship between a higher and lower level of government. For our purposes here, however, this debate is less central than the fact that Kornai is able to identify key political incentives that appear to operate in all socialist systems, arising primarily from the basic principal-agent model above. Viewed from one angle, politics in socialist systems is repressed. But viewed from another, it simply resurfaces within the state and party apparatus in the relationship between different levels of government. Although Kornai naturally focused on economic decision-making processes, these broader relationships of reciprocal accountability and bargaining have been a feature of the analysis of the politics of state socialist systems for some time (for example, Roeder 1993 on the Soviet Union, Shirk 1993 on China).

\section{Late or reformed socialism}

In the third part of The Socialist System, Kornai grapples both with late or reformed socialism and the initial shoots of much deeper reform that emerge with the transitions that I take up in the following section. The operation of the market socialist experiments - including most notably those in Hungary and Yugoslavia - would take me beyond my purposes here; suffice to say that Kornai is quite clear that such tinkering cannot fundamentally address the problems he identified in his analysis of the "classical" system (see particularly Chapters 21-24).

But in the discussion of these reform efforts, which date back to the period following Stalin's death, he re-enforces several points about the political economy 
of socialism that are germane. One has to do with the broader political relationship between state elites and citizens, the other with the elective affinity between single-party dominance and state socialism. Earlier, I alluded to the fact that socialist systems are hardly immune from concerns about citizen welfare, if only because of the fact that coercion carries its own costs and can even be viewed as an inefficient means of maintaining political control. A quite rich strand of political science research explores the nature of the socialist social contract in some detail (see, for example, Cook 1993; Cook - Dimitrov 2017). In outlining trends toward both political and economic reform, Kornai notes that late socialist regimes were becoming more vulnerable to public disaffection with their economic performance (Kornai 1992: 384). He also notes, however, that state elites faced a crisis of confidence, and were caught in a political bind of their own making:

"Brutal repression is a vital disciplinary weapon under the classical system. However, it does not merely afflict the committed opponents of the regime; everyone, even the adherents of the system and the members of the ruling elite, is threatened by it. They too come to demand legal security and legality, at least for themselves. But by doing so they cast doubt on the legitimacy of using repressive measures unconditionally, even though that is one of the basic conditions for the classical system’s stability” (p. 385).

These observations help us understand the fundamental differences between the Chinese and Soviet and Eastern European cases. Chinese growth has remained consistently robust, solving at least temporarily these political constraints from below. The open question is whether elite doubts will become politically significant in the future even if strong performance persists. However, it is simply worth noting that a number of communist systems, as well as many other authoritarian ones, survived the so-called third wave of democratization that included, but was no means limited to, the collapse of the Soviet Union and its Eastern European empire. Economic performance is clearly a factor in these survival cases (Dimitrov 2013), just as - conversely - weak performance helps explain the collapse of dictatorship more generally (Haggard - Kaufman 2016).

A second point that emerges in this section is a restatement of Kornai's conception of why authoritarian rule and the socialist economy are so intimately related. Interestingly, Kornai includes an entire chapter on political liberalization, no doubt motivated in part by the Gorbachev experiment with perestroika and glasnost. Yet he is also clear that such economic reforms will never incrementally lead to fundamental system change until the Communist party's monopoly on power is broken (Kornai 1992: 388). Conversely, once that key monopoly is broken, the path to some kind of market economy is a virtual certainty; it is to those dynamics that I now turn. 


\section{THE POLITICAL ECONOMY OF TRANSITION}

In the fall of 1989, while still working on The Socialist System, Kornai was invited to give a lecture on where Hungary's economic policy should go. The timing was important. Roundtable negotiations had generated an agreement between the government and moderate opposition leaders to hold elections, which ultimately took place and were won by the center-right Hungarian Democratic Forum in April of 1990. The lectures became the nucleus of The Road to a Free Economy (Kornai 1990), which as the title suggests was self-consciously indebted to Hayek's The Road to Serfdom. ${ }^{3}$ Throughout, the book is laced with important observations Kornai was to explore both in his prescriptive work and in his subsequent evaluations of how the transition had gone (for example, Kornai 1997). The book is neatly organized in three sections - on structural change, stabilization, and politics - and I follow that organization in my commentary. A central theme that recurs throughout all of his work is the integral relationship between democratization and the transition to the market (see particularly Kornai 2006).

The section on structural change is titled simply "Ownership," and Kornai appears to pull no punches: the liberalization of entry should be immediate and wide-ranging, property needs to be protected by strong rights, and both the tax system and financial system should not stand in the way of the private sector (either through excessive tax burden or through inadequate credit to it). Kornai believed, and it was true of Hungary to a greater extent than of other transitional cases, that there was already adequate private property and household entrepreneurship to generate a strong supply response to appropriate incentives. Kornai's motives in this regard were both economic and political: to generate a new middle class in the classical sense. Kornai knew that even if reforms were rapid, the process of what he calls "embourgeiosement" would take time. However, the more rapid this fundamentally sociological change the better.

The complexities, of course, were in the state sector and here Kornai's position was more nuanced. Kornai recognized that all state assets were unlikely to be privatized quickly, although he argued strongly for breaking up those firms that could be and selling them off in pieces. Among his more interesting observations, though, was the need to exercise discipline over the state sector that would inevitably be left in government hands. Here, the emerging democratic political

3 The original Hungarian title was Indulatos röpirat a gazdasági átmenet ügyében (A Passionate Pamphlet on Hungarian Economic Transition). As a rare exception to Kornai’s identical handling of the Hungarian original and the translated English versions, the English language edition - and all the subsequent other translations of this short book - contained some modifications as compared to the Hungarian original (chiefly on privatization). Editor's note. 
system entered forcefully into his argument. He believed that the bureaucracy remained vulnerable to the same politics that had plagued the socialist system and generated SBC. Interestingly, he saw a, if not the, crucial role of parliament to be in exercising checks on the state that were wholly missing in the fused communist status quo ante. In particular, these checks would take the form of imposing a hard budget constraint on state firms. Managers would get leeway with respect to all investment, production, and marketing decisions, but not at public expense. Although it is often believed that democracies are vulnerable to the SBC problem, Kornai believed that the wider public interest in the integrity of public finances provided the political foundation for democratic discipline.

With respect to stabilization in the transitional economies, a central debate was whether it could be done quickly or whether political as well as economic constraints argued for a gradual path. Kornai is unambiguous on this point. The central task of controlling inflation and re-establishing fiscal equilibrium must be accomplished quickly, and Kornai makes the argument partly on distributional grounds: that inflation itself has the effect of allocating resources, and in a distinctly inauspicious way from the perspective of the development of the private sector.

As can be seen, political factors are laced through the analysis of both the requisite structural changes in the economy and the stabilization process. In particular, Kornai sides with those who argue that moving quickly has a number of political advantages: it exploits the transitional moment when support for the government is likely to be high and sets in train forces which unfold more slowly - such as the emergence of the private sector - but that ultimately have self-reenforcing effects for his favored policies.

At the end of his discussion of politics (pp. 206-209), he explicitly raises the question of whether a Pinochet is required to institute shock therapy. His response is "no", not only on normative, but on positive grounds. While a "strong" government is indeed necessary to undertake such a program, that strength can arise from a representative government that enjoys wide support. As a result, the last section of the book explicitly considers how such broad coalitions of support can be rallied and potential opposition managed.

Some bases of support are relatively obvious, and they are both material and ideological: those committed to liberal ideas and the promise of freedom; those wishing to form businesses; and those who have or want to acquire property. But he also sees a positive appeal in promising to end inflation and the shortage economy and stopping the squandering of public resources.

On the other hand, he recognizes where resistance is most likely to arise. Some of these sources of opposition simply cannot be finessed; democratic leaders need to make difficult choices. For example, he argues strongly for wage discipline 
with respect to public sector workers, both on structural and stabilization grounds (p. 65, pp. 142-145). With respect to unemployment, he observes a nuanced principle of compensation. The government should provide transitional support and address issues of outright poverty. Yet this should be done in the context of a stated expectation that households and individual workers need to take initiative and shift their work effort in line with the structural changes unleashed by the transition. As with all market-oriented liberalism, Kornai advances an ethic of responsibility. He clearly believes such an ethic was missing from the depersonalized nature of property and employment in the socialist system, and constitutes perhaps one of its most pernicious cultural legacies.

A full discussion of how Kornai viewed the transition would take us beyond the purpose of this brief appreciation. On the one hand, his overall evaluation was unambiguously positive and even in line with a Whig view of history as the march toward greater freedom (particularly Kornai 2006). On the other hand, Kornai was perfectly aware of the complications introduced as a result of the transition, and particularly with respect to social issues. Inequality and unemployment are features of capitalist systems, but particularly when transitioning from a socialist past. And with those material changes necessarily came a variety of social psychological problems and resentments. Not surprisingly, Kornai's subsequent work was often seized of these social issues, for example in his long-standing interest in the political economy of healthcare (Kornai 2001; Kornai - Eggleston 2001). Perhaps more than any other possible issue area, the analysis of healthcare provided an opportunity to consider the complex set of political economy questions raised here, from the perils of a soft-budget constraint in an arena in which demand always outstrips supply to the ethical problems of defining what he called the "spheres of authority of the citizen and the state” (Kornai 2001).

\section{BY WAY OF CONCLUSION: U-TURN}

I want to close with an unfortunate coda to Kornai's career, yet one which shows once again his independence of mind and intellectual courage. Long a champion of democracy, both in principle and in his native Hungary, he was moved - even forced - to raise his voice on the issue in 2015 (Kornai 2015). In an important piece that was widely translated and read called "Hungary's U-Turn", he called out growing authoritarian tendencies in the Hungarian political system. As with other cases of what political scientists have called "backsliding," the route to competitive authoritarian rule did not follow the traditional path of the coup (see his reflections on these analytic issues on pp. 13-15). Rather, incumbents ex- 
ploited majoritarian features of a political system, as Putin had in Russia and Erdogan in Turkey, to undermine horizontal checks on executive power and civil and political liberties.

In 2010, the year following the global financial crisis, Fidesz won an overwhelming electoral victory in Hungary, with 54 percent of the popular vote. The system of representation, however, favored the largest party and Orbán's victory thus translated into a two-thirds parliamentary majority. With Fidesz in control of a supermajority and the mainstream parties devastated, Orbán was not only able to move the political system sharply to the right, but to centralize his own personal power. Worse still, a number of inter-related institutional derogations followed: a constitutional change, the reduction of the Parliament to what Kornai neatly labels a "bill factory," to the weakening of the independence of the judiciary, and ultimately of civil and political liberties as well.

These facts are now well-known, but not so obviously seen at the time; Kornai was relentlessly critical of Orbán's apologists. Yet here, it is only worth underlining a theme that runs through the full body of work reviewed here: the close relationship Kornai saw between democracy and the market, and conversely the deleterious economic effects of political centralization. As is visible in the epigraph to this paper, it is not the private sector that matters for understanding these phenomena, but rather state power. As he puts it in discussing the new Hungary, "we are not talking about a case of 'state capture' carried out by a small group of oligarchs in order to establish regulations and pass measures in their own interests. The direction of the process is the reverse. Orbán and the people who are close to him at the peak of political power decide who should become an oligarch, or who should remain an oligarch if he already is one, and how far his sphere of authority should extend" (p. 7). These processes occur in a purposefully blurred ideological milieu in which extensive corruption goes unchecked at the same time that populist appeals are used to paper over the malfeasance of the government's own economic cronies. The result: if not a return to socialism, as Kornai claims, at least a reversion to some sort of hybrid state capitalism with the risks of a soft budget constraint and a variety of microeconomic distortions on ample display.

In his intellectual biography (Kornai 2007) and throughout his career, Kornai called on economists to wade into the central controversies of their time and to make themselves useful. His J'Accuse with respect to the Orbán government is by no means out of character. In re-reading his work, I think the frustration with GET theory that motivated Anti-Euqilibrium might have been grounded in just such concerns: "what do we do with a theory of this sort?". The answer to that question is easily answered with respect to Kornai's own political economy: plenty! 


\section{REFERENCES}

Arrow, K. J. (1951): Social Choice and Individual Values. New York: John Wiley\&Sons.

Arrow, K. J. - Debreu, G. (1954): Existence of Equilibrium for a Competitive Economy. Econometrica, 22(3): 265-290.

Cook, L. J. (1993): The Soviet Social Contract and Why It Failed: Welfare Policy and Workers' Politics from Brezhnev to Yeltsin. Cambridge: Harvard University Press.

Cook, L. J. - Dimitrov, M. (2017): The Social Contract Revisited: Evidence from Communist and State Capitalist Economies. Europe-Asia Studies, 69(1): 8-26,

Dimitrov, M. (2013): Why Communism Did Not Collapse: Understanding Authoritarian Regime Resilience in Asia and Europe. New York: Cambridge University Press.

Haggard, S. - Kaufman, R. (2008): Development, Democracy and Welfare States: Latin America, East Asia and Eastern Europe. Princeton: Princeton University Press.

Haggard, S. (2016): Dictators and Democrats: Masses, Elites and Regime Change. Princeton: Princeton University Press.

Hahn, F. H. (1975): The Winter of Our Discontent. Economica, New Series, 40(159): 322-330.

Hayek, F. (1944): The Road to Serfdom. London: Routledge

Kornai, J. (1959/1994): Overcentralization in Economic Administration: A Critical Analysis Based on Experience in Hungarian Light Industry. Oxford: Oxford University Press.

Kornai, J. (1971): Anti-Equilibrium. Amsterdam: North-Holland.

Kornai, J. (1979): Resource-Constrained versus Demand-Constrained Systems. Econometrica, 47(4): 801-819.

Kornai, J. (1980): Economics of Shortage. Amsterdam: North-Holland.

Kornai, J. (1986): The Soft Budget Constraint. Kyklos, 39(1): 3-30.

Kornai, J. (1990): The Road to a Free Economy: Shifting from a Socialist System: The Example of Hungary. New York: W.W. Norton.

Kornai, J. (1992): The Socialist System: The Political Economy of Socialism. Princeton: Princeton University Press.

Kornai, J. (1997): Struggle and Hope: Essays on Stabilization and Reform in a Post-Socialist Economy. Cheltenham: Edward Elgar.

Kornai, J. (1998): The Place of the Soft Budget Constraint Syndrome in Economic Theory. Journal of Comparative Economics, 26: 11-17.

Kornai, J. (2001): The Borderline between the Spheres of Authority of the Citizen and the State: Recommendations for the Hungarian Health Reform. In: Kornai, J. - Haggard, S. - Kaufman, R. (eds): Reforming the State: Fiscal and Welfare Reform in Post-Socialist Countries. Cambridge: Cambridge University Press. pp. 181-209.

Kornai, J. (2006): The Great Transformation of Central Eastern Europe. Economics of Transition, 14(2): 207-244.

Kornai, J. (2007): By Force of Thought: Irregular Memoirs of an Intellectual Journey. Cambridge: MIT Press.

Kornai, J. (2015): Hungary's U-Turn. Capitalism and Society, 10(1): 1-24.

Kornai, J. - Eggleston, K. (2001): Welfare, Choice and Solidarity in Transition: Reforming the Health Sector in Eastern Europe. Cambridge: Cambridge University Press.

Kornai, J. - Liptak, T. (1965): Two-Level Planning. Econometrica, 33(1): 141-169.

Krueger, A. O. (1974): The Political Economy of the Rent-Seeking Society. American Economic Review, 64(3): 291-303.

Magaloni, B. - Kricheli, R. (2010): Political Order and One Party Rule. Annual Review of Political Science, 13(1): 13-143. 
Moe, T. (1984): New Economics of Organization. American Journal of Political Science, 28(4): 739-777.

Przeworski, A. (1991): Democracy and the Market: Political and Economic Reforms in Eastern Europe and Latin America. Cambridge: Cambridge University Press.

Roeder, Ph. (1993): Red Sunset: The Failure of Soviet Politics. Princeton: Princeton University Press.

Schurman, F. (1966): Ideology and Organization in Communist China. Berkeley: University of California Press.

Shirk, S. (1993): The Political Logic of Economic Reform in China. Berkeley: University of California Press.

Skocpol, T. (1979): States and Social Revolutions. New York: Cambridge University Press. 